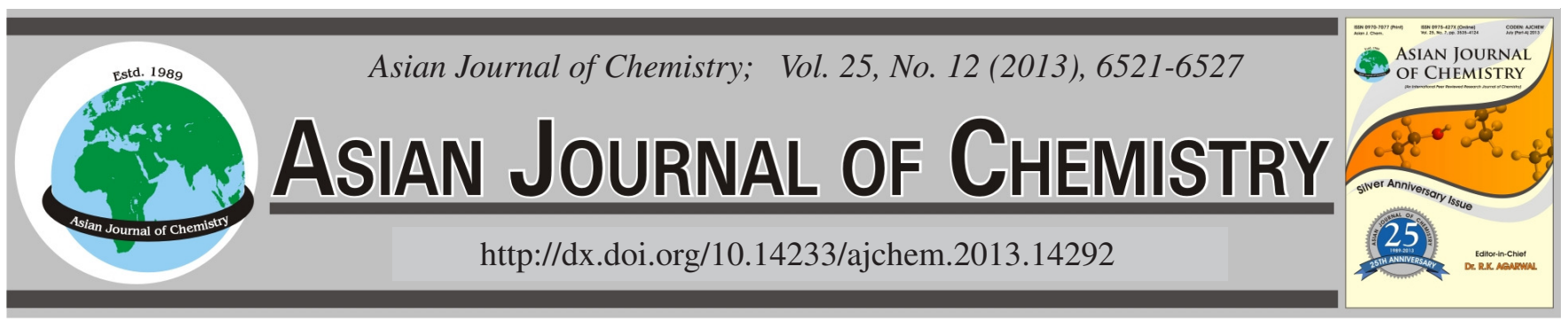

\title{
Detection of Fenton's Reagent with Carbamide Peroxide on Heterobasidion insulare Negative Influence and Degradation of Polycyclic Aromatic Hydrocarbons in Contaminated Soil Relocation of Petrochemical Works
}

\author{
Yue-Hua Zhang ${ }^{1,2}$, JiA-Lin Li $^{2}$, Tian-Lin Miu' ${ }^{1}$ and Zhe-Wen Luo ${ }^{1, *}$
}

${ }^{1}$ College of Life Science, Jiamusi University, Jiamusi, Heilongjiang Province, P.R. China

${ }^{2}$ Institute of Applied Microbiology, Jiamusi University, Jiamusi, Heilongjiang Province, P.R. China

*Corresponding author: E-mail: jiamusiluozhiwen@126.com

(Received: 12 July 2012;

Accepted: 20 May 2013)

AJC-13513

\begin{abstract}
During cultivation of the soil experiment, degradation of polycyclic aromatic hydrocarbons from the migrated petrochemical works contaminated soil by modified Fenton's reaction with carbamide peroxide in laboratory column tests and subsequent aerobic biodegradation of polycyclic aromatic hydrocarbons by native bacteria. The effect of carbamide peroxide addition for 4 and 10 days and saturation of soil with carbamide peroxide was experiment. In both tests the carbamide peroxide dosage was $0.8 \mathrm{~g}$ soil. In completely hydrogen peroxide urea saturated soil the degradation of polycyclic aromatic hydrocarbons ( $44 \%$ within 4 days) by modified Fenton's with carbamide peroxide reaction was uniform over the entire soil column. Compared to partially saturated soil with $25 \%$ in 2 weeks, the effect of the modified Fenton's reaction with carbamide peroxide on the microbial activity in the soil was evaluated based on toxicity experiment with Heterobasidion insulare, checklist of viable and dead cells, microbial extra cellular enzyme activity and oxygen consumption and carbon dioxide production during soil cultivation. As the hydrogen peroxide urea is broken down into oxygen and nitrogen, promote the breeding of indigenous microorganisms. In the tests, the toxicity of column leachate with Heterobasidion insulare increased due to the modified Fenton's reaction with carbamide peroxide. In untreated soil $20-30 \%$ of the polycyclic aromatic hydrocarbons were biodegraded in 8 weeks of cultivation. Cultivation of bio-chemically treated soil slightly increased polycyclic aromatic hydrocarbons-degradation compared to polycyclic aromatic hydrocarbons degradation in untreated soil.
\end{abstract}

Key Words: Biodegradation, Heterobasidion insulare, Carbamide peroxide, Fenton's reagent, Polycyclic aromatic hydrocarbons.

\section{INTRODUCTION}

Clean-up processes for soils contaminated with polycyclic aromatic hydrocarbons have been limited by high-cost on-site stabilization and excavation followed by subsequent off-site incineration. In situ remediation of migrated petrochemical works contaminated soils is considered more cost efficient than on-site and off-site treatment ${ }^{1}$. Polycyclic aromatic hydrocarbons (PAHs) are widespread and large numbers contaminants of soils and sediments, especially for in migrated petrochemical works contaminated soil. Advanced oxidation processes, such as modified Fenton's reaction and biodegradation are promising in situ remediation techniques. The in situ biodegradation of high molecular weight polycyclic aromatic hydrocarbons usually occurs slowly ${ }^{2}$.

There are two important parameters which affect the degradation of petroleum hydrocarbons in soil are aeration and nutrients, particularly nitrogen. Carbamide peroxide provides both $\mathrm{O}_{2}$ and $\mathrm{N}$ upon catalysis by catalase and urease, respectively, in contaminated soils ${ }^{3}$. The combined application of one amendment for in situ bioremediation of hydrocarbons is favourable over several treatments. The addition of carbamide peroxide for in situ treatment has many advantages including provides both aeration and $\mathrm{N}$. the carbamide peroxide is highly mobile and increases the stability than $\mathrm{H}_{2} \mathrm{O}_{2}$. Carbamide peroxide is non-toxic at high concentrations to the native microorganisms. It provides higher $\mathrm{O}_{2}$ concentrations compared to soil venting and it does not volatilize the pollutant and bio-fouling is not a problem as found in forced air systems.

In advanced oxidation processes highly reactive radicals, Such as hydroxyl radicals $\left({ }^{\circ} \mathrm{OH}\right)$, capable of oxidizing persistent organic contaminants are formed. In the original Fenton's reaction, the radicals are formed during the reaction of dilute $\mathrm{H}_{2} \mathrm{O}_{2}$ solution with $\mathrm{Fe}(\mathrm{II})$, the so-called Fenton's reagents. In Fenton-like reactions Fe(III) instead of Fe(II) is used, whereas modified Fenton's reactions apply concentrated $\mathrm{H}_{2} \mathrm{O}_{2}$ solutions, iron chelating agents or iron containing minerals at Circum 
neutral $\mathrm{pH}$. Modified Fenton's reactions have been used in the clean-up of soils contaminated with such as polycyclic aromatic hydrocarbons ${ }^{4,5}$ and pentachlorophenol (PCPs) ${ }^{6}$. A short-term chemical oxidation process combined with biodegradation may enhance polycyclic aromatic hydrocarbon degradation more than natural processes, because partially oxidized metabolites of the polycyclic aromatic hydrocarbon are more water-soluble and thus more bioavailability ${ }^{7}$.

The carbamide peroxide used and the radicals formed in the Fenton's reaction are inhibition of soil microbial. Therefore, reduce the abundance of viable cells. Earlier studies focused on the combination of Fenton's reaction with addition of microbial enrichment as sediment or mixed cultures ${ }^{4,5}$. If the number of viable and polycyclic aromatic hydrocarbondegrading bacteria could be maintained during the Fenton's reaction, subsequent addition of bacteria would not be necessary. The low $\mathrm{pH}$ of 2-3 required for a standard Fenton's reaction can disturb the soil ecosystem and thus, may be not suitable for with biological treatment ${ }^{5}$. Thus, in this study with modified Fenton's react ion, the soil $\mathrm{pH}$ was not acidified prior to $\mathrm{H}_{2} \mathrm{O}_{2}$ addition to minimize stress on the soil bacteria. Two different intensities of $\mathrm{H}_{2} \mathrm{O}_{2}$ addition, with applying the $\mathrm{H}_{2} \mathrm{O}_{2}$ at two different periods of time, were tested in laboratoryscale simulation of in situ remediation of soil contaminated with migrated petrochemical works in mainly polycyclic aromatic hydrocarbons.

The oxidized metabolites of polycyclic aromatic hydrocarbons have been thick to be more toxic to Heterobasidion insulare than the parent compounds ${ }^{8}$ and thus, the chemically treated soil may be more toxic to bacteria than untreated soil. Heterobasidion insulare is very sensitive bacterial strains for environmental testing ${ }^{9}$. In this laboratory study, possible toxic and inhibitory effects of modified Fenton's reaction with carbamide peroxide to soil bacteria were monitored with analyses of migrated petrochemical works contaminated soil and leachate toxicity in Heterobasidion insulare and native microbial extra cellular enzymatic activity in contaminated soil. The degradation of polycyclic aromatic hydrocarbons from soil was determined immediately after modified Fenton's reaction and after cultivation. In this study microbial activity after oxidation and following cultivation was determined with analyses of bacterial abundance and activity of microbial extracellular enzymes as well as monitoring of concentrations of $\mathrm{O}_{2}, \mathrm{CO}_{2}$ and $\mathrm{CH}_{4}$ during cultivation.

\section{EXPERIMENTAL}

Migrated petrochemical works contaminated soil column tests: In current full-scale applications of modified Fenton reaction with carbamide peroxide, the Fenton reagents are delivered to contaminated soil via injection. As results, in this experiments were carried out in packed soil columns with a carbamide peroxide aqueous solution as concentration gradient in delivery system simulating in situ injection. Such experiments were performed at room temperature about 20-27 ${ }^{\circ} \mathrm{C}$. The effect of a higher experimental temperature compared to in situ temperature was considered overlooked, because of the Fenton reaction is exothermic and thus soil temperature will increase during in situ treatment.

The sample site is located in an esker and the bed rock in depth of $2 \mathrm{~m}$ is overlaid by sand, gravel and powder soil. Treatment of migrated petrochemical works contaminated soil was studied in laboratory-scale down-flow soil columns simulating field applications. Jiamusi city, migrated petrochemical works contaminated soil (Table-1) was sampled from an abandoned main plant, in which the production of industrial activities started in 1987a. The contamination of the soil occurred approximately in the 1980s, due to a leak in a storage tank or uncontrolled procedures for operating. The highest contaminant concentrations are located above the bed-rock surface. the sample sieved $(<0.6 \mathrm{~cm})$ contaminated soil was packed to a density of $1.20 \mathrm{~g} / \mathrm{cm}^{3}$ into duplicate acrylic resin columns with inner diameter $10 \mathrm{~cm}$. The studied soil was rich in iron (Table-1) and thus iron was not repeated added in the experiments. A carbamide peroxide dosage of $0.8 \mathrm{~g}$ as $100 \%$ $\mathrm{H}_{2} \mathrm{O}_{2} / 2 \mathrm{~g}$ soil was applied within 4 days (500 g contaminated soil) and 10 (700 g contaminated soil) days' treatment times, respectively (Table-2).

\begin{tabular}{|c|c|c|c|c|c|}
\hline \multicolumn{6}{|c|}{$\begin{array}{l}\text { TABLE-1 } \\
\text { SOIL CONTENT OF C, N, P, POTENTIAL FENTON'S REACTION CATALYSTS, i.e. } \\
\text { Fe AND Mn, AND POLYCYCLIC AROMATIC HYDROCARBONS (PAHs) }\end{array}$} \\
\hline Compound & $\begin{array}{l}\text { Concentration } \\
(\mathrm{mg} / \mathrm{kg})^{*}\end{array}$ & $\begin{array}{c} \pm \text { Standard deviation } \\
\left(\mathrm{mg} \mathrm{kg}^{-1} \text { dry soil }\right)\end{array}$ & Compound & $\begin{array}{l}\text { Concentration } \\
(\mathrm{mg} / \mathrm{kg})^{*}\end{array}$ & $\begin{array}{c} \pm \text { Standard deviation } \\
\left(\mathrm{mg} \mathrm{kg}^{-1} \text { dry soil }\right)\end{array}$ \\
\hline Total C & 22020 & 31.3 & Fluorene & 421 & 14 \\
\hline Total P & 190 & 22.7 & Phenanthrene & 560 & 39 \\
\hline Total Fe & 19850 & $3212(95 \%$ confidence level) & Anthracene & 170 & 26 \\
\hline Total Mn & 89 & 41 (95\% confidence level) & Fluoranthene & 1321 & 90 \\
\hline Napthalene & Low limit & - & Pyrene & 598 & 54 \\
\hline Acenaphthene & 329 & 16 & Benz(a)anthracene & 190 & 21 \\
\hline Total PAHs & 3780 & 245 & Chrysene & 200 & 20 \\
\hline
\end{tabular}

*Concentrations are mean values of five determinations SD $(\mathrm{mg} / \mathrm{kg})$.

TABLE-2

SET-UP OF THE COLUMN EXPERIMENTS. CARBAMIDE PEROXIDE (CP) DOSE AS $100 \%$ HYDROGEN WAS 0.4 g CP/g SOIL

\begin{tabular}{lccccc}
\hline \multicolumn{1}{c}{ Experiment } & $\begin{array}{c}\text { Treatment } \\
\text { time }(\mathrm{d})\end{array}$ & $\begin{array}{c}\text { 3 Injections per day } \\
(\mathrm{mL} / \text { injection) }\end{array}$ & $\begin{array}{c}\text { Total volume injected } \\
\text { to each column }(\mathrm{mL})\end{array}$ & $\begin{array}{c}\text { Soil } \\
\text { content }(\mathrm{g})\end{array}$ & $\begin{array}{c}\mathrm{CP} \text { dose as } \\
100 \% \mathrm{H}_{2} \mathrm{O}_{2} / \mathrm{g} \text { soil }\end{array}$ \\
\hline Shorter treatment time & 4 & $50(\mathrm{CP})$ & 600 & 500 & 0.36 \\
Longer treatment time & 10 & $25(\mathrm{CP})$ & 750 & 700 & 0.34 \\
Control with deionized water & 10 & $25(\mathrm{CP})$ & 750 & 700 & 0 (injection of $\left.\mathrm{H}_{2} \mathrm{O}\right)$ comparison \\
\hline
\end{tabular}


In the longer treatment experiment upper soil remained unsaturated due to the smaller injection volumes for this (Table2 ). The $40 \%$ carbamide peroxide solution was injected about 4-5 $\mathrm{cm}$ below soil surface into the columns in Teflon tubes with arranged in holes three times per day. The washing of contaminants out of the column due to liquid injection was studied in a control experiment in which deionized water instead of aqueous solution of carbamide peroxide was added to the soil for 10 days. Column leachates were collected after each injection of carbamide peroxide aqueous solution. In leachate, the residual carbamide peroxide aqueous solution was removed by addition of catalase or $5 \% \mathrm{Na}_{2} \mathrm{SO}_{3}$ so as to excess to terminate the oxidation reactions and in prevent of inhibition of bacteria by high $\mathrm{H}_{2} \mathrm{O}_{2}$ concentrations. The untreated soil and soil from the columns after the modified Fenton's reaction with up, i.e. from the upper and lower part of the columns, were collected for analyses. Residual carbamide peroxide was not removed from the sample soil.

Heterobasidion insulare cultivation experiments: Control soil was prepared by autoclaving the soil $\left(121^{\circ} \mathrm{C}, 1\right.$ h) twice with three days in between interval in order to kill spore-forming bacteria. Soil samples, including control, were incubated in sealed bottles at $20{ }^{\circ} \mathrm{C}$ for 5-16 weeks.

Chemical analyses: Carbon and $\mathrm{N}$-concentrations in the sieved soil were determined with a $\mathrm{C}, \mathrm{N}$-analyzer and metals as well as $\mathrm{P}$ and $\mathrm{S}$ in the soil were extracted in $\mathrm{HCl}-\mathrm{HNO}_{3}$ mixture, $3: 1$ ratio, at $90^{\circ} \mathrm{C}$. Dry matter content of soil samples was determined by oven-drying at $105{ }^{\circ} \mathrm{C}$ overnight. The extract was analyzed with inductively coupled plasma atomic emission spectrometer (IRIS-AP), Thermo US Co. Ltd. Soil $\mathrm{pH}$ was determined with a $\mathrm{pH}$ meter from soil mixed with deionized water according to the ASTM standard method D618-61 ${ }^{3}$.

From the gas phase of the sealed serum bottles $\mathrm{O}_{2}, \mathrm{CO}_{2}$ and $\mathrm{CH}_{4}$ were determined with gas chromatograph equipped with thermal conductivity detector (Aglient-6890). Before the gas measurements excess pressure was removed with a gas syringe and the volume was recorded as parameter compensation. Thereafter, the soil samples were taken and the bottles were resealed for further cultivation.

The polycyclic aromatic hydrocarbons were extracted from soil samples $5 \mathrm{~g}$ dried with anhydrous $\mathrm{Na}_{2} \mathrm{SO}_{4}$ with dichloromethane $(60 \mathrm{~mL})$ in a Soxhlet apparatus for $16 \mathrm{~h}$ at $105^{\circ} \mathrm{C}$. The extracts were diluted with dichloromethane and filtered $(0.2 \mu \mathrm{m})$ prior to analysis. Internal standard (Phenanthrene-deuterated) was added into the vials. As a solution containing 16 polycyclic aromatic hydrocarbons (Polynuclear Aromatic Hydrocarbons Mix, EPA 610, Accu standard) was used as external standard. The extracts were analyzed with AGILENT 6890 GAS CHROMATOGRAPHY equipped with a mass-selective detector (GC-MS) using selected ion monitoring. Further, from the filtered $(0.45 \mu \mathrm{m})$ leachate samples the polycyclic aromatic hydrocarbons were extracted with dichloromethane. Dichloromethane extracts were concentrated under nitrogen stream to final volume and the polycyclic aromatic hydrocarbons were analyzed.

Bioluminescence toxicity assay: The toxicity of leachates as determined to follow the formation of toxic metabolites during the modified Fenton's reaction. Toxicity of samples to Heterobasidion insulare was deter cultivation assay modified from $^{10}$. Catalase treated column leachates were combined with the toxicity analysis experiment. The toxicity of soil was also determined to investigate the effect of residual carbamide peroxide and cultivation. The assay accounts for the colour and turbidity caused by soil particulate matter. Before to measurement, $6 \mathrm{~g}$ of $3 \% \mathrm{NaCl}$ solution were added to $2 \mathrm{~g}$ of soil to obtain ratios of $1: 3$ and 1:4, respectively. The serial dilutions were prepared from these solutions by addition of $2 \% \mathrm{NaCl}$ solution in a 1:1 ratio. Leachate samples were first diluted with $2 \% \mathrm{NaCl}$ solution 1:2 and 1:3 and then as before. The end solutions were adjusted to $\mathrm{pH}$ 6-8 with $0.1 \mathrm{M} \mathrm{NaOH}$. The operating assay was performed in 96 -well plates and $150 \mu \mathrm{L}$ of each sample dilution were added to duplicate control wells. $\mathrm{NaCl}$ solution $(3 \%, 150 \mu \mathrm{L})$ was added to 4 control blank wells. The resuscitation of lyophilized Heterobasidion insulare was rehydrated and dilution according to Bio tox kit instructions was used to dispense $150 \mu \mathrm{L}$ of Heterobasidion insulare solution to a well and to measure as the same time, the luminescence intensity in the well. The kinetic measurement, at $50 \mathrm{~ms}$ intervals up to 1000 measurements, was continued for $30 \mathrm{~s}$ and each well was measured, again, after $30 \mathrm{~min}$ for $1 \mathrm{~min}$. Inhibition percent ages (INH \%) were calculated using following equation:

$$
\mathrm{INH}(\%)=100-100 \times \frac{\mathrm{IT}_{\mathrm{t}} \times \mathrm{IC}_{0}}{\mathrm{IT}_{0} \times \mathrm{IC}_{\mathrm{t}}}
$$

where IC is the luminescence intensity of the control sample after contact time $\mathrm{t}, \mathrm{IC}_{0}$ the maximum luminescence intensity of control sample, IT $_{t}$ the luminescence intensity of the test sample after contact time $\mathrm{t}$ and $\mathrm{IT}_{0}$ the maximum luminescence intensity of the test sample. $\mathrm{EC}_{50}$ values were calculated by plotting inhibition percent ages against dilution.

Check-list of dead and viable bacteria: Live/Dead ${ }^{\circledR}$ BacLight TM Bacterial Viability Kit and propidium-iodide stains (Viability Kit L-7012, Molecular Probes) was used to determine the viability based on cell wall integrity of bacteria in treated and untreated soil. Soil $1 \mathrm{~g}$ was mixed with $50 \mathrm{~mL}$ sterile deionizer water and the suspension was ultrasound ( $5 \mathrm{~min}$ ). The suspension (from 50 to $100 \mu \mathrm{L}$ ) was mixed with $0.01 \mathrm{M} \mathrm{Na}_{4} \mathrm{P}_{2} \mathrm{O}_{7} \cdot 10 \mathrm{H}_{2} \mathrm{O}$ to achieve final volume of $1 \mathrm{~mL}$ in an Eppendorf tube. The final suspension and Eppendorf tube rinsing liquid $\left(0.1 \mathrm{M} \mathrm{Na}_{4} \mathrm{P}_{2} \mathrm{O}_{7} \cdot 10 \mathrm{H}_{2} \mathrm{O}\right)$ was filtered with polycarbonate membrane filter $(0.2 \mu \mathrm{m})$, supported by cellulose acetate filter $(0.45 \mu \mathrm{m})$. No more than 130 cells per filter were enumerated with a fluorescence system microscope.

Microbial extracellular enzymatic activity in soil: The activity of microbial extracellular enzymes was followed in soil samples to determine the effect of the modified Fenton's reaction. The stock and working solutions of enzyme substrates and the model fluorogenic molecules, 7-amino-4-methyl coumarin (AMC) and 4-methyl umbelliferone (MUF) and were prepared in dimethyl sulfoxide due to the low water solubility of the substances. The concentrations of model substrates in the assay were 1-500 $\mu \mathrm{mol} / \mathrm{L}$ for L-leucine-7-AMC, L-alanine7-AMC and L-serine-7-AMC hydrochloride, from 0.5 to 200 $\mu \mathrm{mol} / \mathrm{L}$ for 4-MUF-phosphate potassium salt and from 2 to 
$1000 \mu \mathrm{mol} / \mathrm{L}$ for 4-MUF acetate. Standard solution of MUF and AMC $(0.1-50 \mu \mathrm{mol} / \mathrm{L})$ were prepared in duplicates in soil solutions i.e. standard curves were prepared separately for each sample to take into account possible quenching of the fluorescence by soil particles. The soil samples from untreated and treated $(0.6 \mathrm{~g}$ as $100 \%$ carbamide peroxide/g soil) were first suspended 1:50 in sterile deionized water (Milli-Q) and ultrasonic wave $(5 \mathrm{~min})$. The soil suspension $(90 \mu \mathrm{L})$ was transferred to each of the wells in a 96-well micro-titer plate. The soil suspension was not buffered to investigate the potential enzyme activity at field conditions.

The fluorescence of the hydrolyzed model substrates and standards was measured at excitation $355 \mathrm{~nm}$ and emission $460 \mathrm{~nm}$ with a fluorometer immediately after addition of soil suspension soil, 1 and $3 \mathrm{~h}$. The rates of hydrolyzed enzyme substrate were calculated for dry soil to enable comparison of soil samples with different moisture content. The potential maximum rate of microbial extracellular enzyme hydrolysis is referred in text as $\mathrm{v}^{*}{ }_{\max }$.

\section{RESULTS AND DISCUSSION}

Degradation of polycyclic aromatic hydrocarbons during cultivation experiments and column: Naphthalene was not detected in the migrated petrochemical works contaminated soil (Table-1), although in migrated petrochemical works, naphthalene and phenanthrene are the most abundant polycyclic aromatic hydrocarbons of the 16 polycyclic aromatic hydrocarbons identified as priority pollutants by EU and US EPA ${ }^{11}$. This means that naphthalene had either volatilized or degraded prior to soil sampling and during storage of the samples. The soil was rich in iron $(16.4 \mathrm{~g} / \mathrm{kg}$ soil) (Table1 ), thus eliminating the need for iron supplementation. Due to injection of acidic $30 \% \mathrm{H}_{2} \mathrm{O}_{2}$ solution ( $\mathrm{pH}$ at 2-3), the $\mathrm{pH}$ of the column leachate decreased to 2, thus optimal for Fenton's reaction $^{12}$. The soil $\mathrm{pH}$ was slightly acidic (5-6) and the $\mathrm{pH}$ remained stable throughout the modified Fenton's reaction. Also other studies showed that soil $\mathrm{pH}$ remained stable during addition of hydrogen peroxide ${ }^{10,13}$, likely due to buffering capacity of soils. Therefore, additional adjustment of the soil $\mathrm{pH}$ was not carried out. In the 4-day experiment, the soil was saturated with $\mathrm{H}_{2} \mathrm{O}_{2}$ solution throughout the entire study, while only the lower part of the soil was saturated with $\mathrm{H}_{2} \mathrm{O}_{2}$ in the 10-day experiment. In the 10 days treatment, the degradation in the lower part of the soil columns was higher (52\%) than in the upper part of the column (25\%). In the completely saturated soil, polycyclic aromatic hydrocarbon-degradation was uniformly $44 \%$ within 4 days (Fig. 1). This polycyclic aromatic hydrocarbon degradation is lower compared to the results obtained $^{5}$ of a degradation of $80-99 \%$ of naphthalene, fluorene and phenanthrene in a slurry of coal-tar contaminated soil. This could be due to an improved mass transfer in stirred soil slurry ${ }^{14}$. For higher molecular weight polycyclic aromatic hydrocarbons degradation was 20-40\%.

$10 \%$ of the polycyclic aromatic hydrocarbons, mainly 2and 3-ring polycyclic aromatic hydrocarbons, approximately, were removed from the contaminated soil by injection of deionized water into the control column for 10 days. The decrease of polycyclic aromatic hydrocarbon-concentration in control was treatment with sole water of $20 \%$ within a study on Fenton oxidation of polycyclic aromatic hydrocarbons ${ }^{15}$. The degradation of mainly 2- and 3-ring polycyclic aromatic hydrocarbons may be due to their bigger water solubility compared to polycyclic aromatic hydrocarbons with more aromatic rings. However, the water solubility accounts only partially for the measured polycyclic aromatic hydrocarbon removal. Dissolved organic matter increases the water solubility of hydrophobic pollutants ${ }^{16-18}$, whereas bioavailability of polycyclic aromatic hydrocarbons decreases by sorption to organic matter ${ }^{19,20}$. Therefore, it is likely that most of the polycyclic aromatic hydrocarbons were removed from the column being adsorbed onto the suspended solids of the leachate.

On average, $31 \%$ of polycyclic aromatic hydrocarbons were removed during 2 months of cultivation of untreated contaminated soil (Fig. 1, untreated soil). Thus, approximately $31 \%$ of the polycyclic aromatic hydrocarbons were available for aerobic biodegradation at $20{ }^{\circ} \mathrm{C}$. The degradation of

\begin{tabular}{|ll|}
$\square$ Initial PAHs concentration & $\square$ Treanment not incubation \\
$\square$ 8 weeks incubation & $\square$ 16 weeks incubation \\
\hline
\end{tabular}

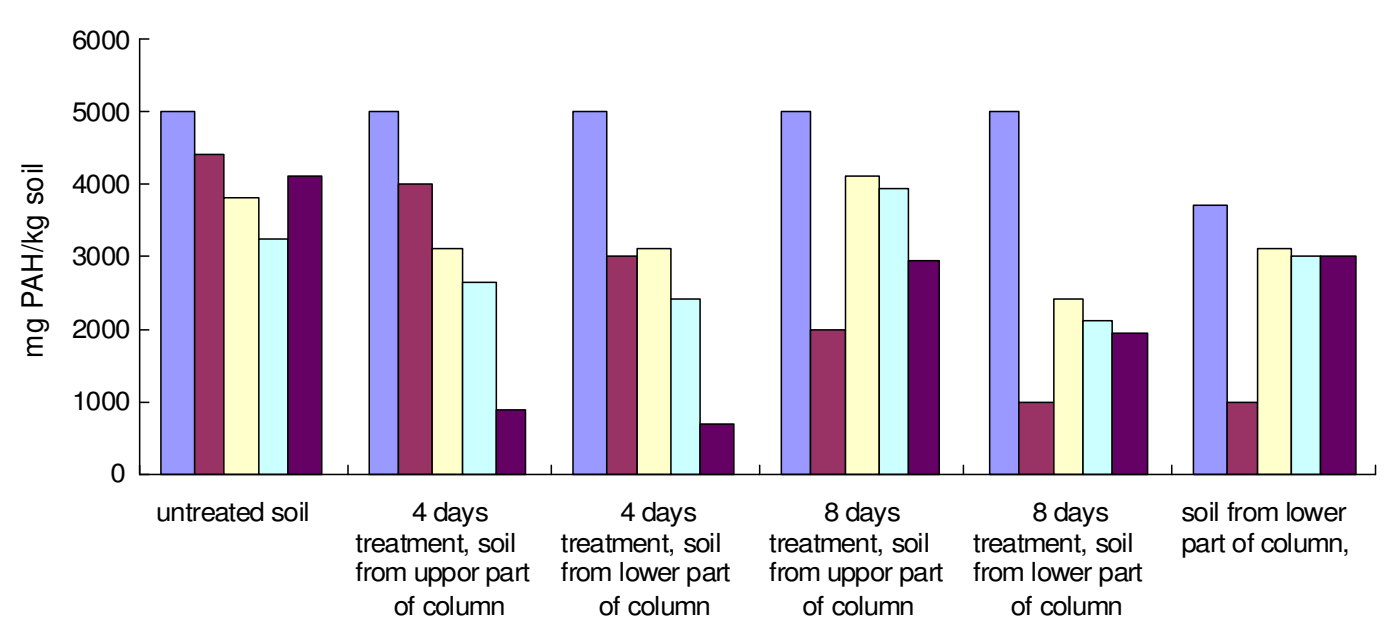

Fig. 1. Polycyclic aromatic hydrocarbon concentration in soil after modified Fenton's with carbamide peroxide cultivation of control treatment in soil 
polycyclic aromatic hydrocarbons during cultivation of soil from the control column was $12 \%$ (Fig. 1, soil from control column). The degradation of polycyclic aromatic hydrocarbons from soil treated with modified Fenton's reaction was up to $15 \%$ (increase from 25 to $36 \%$ ) during cultivation, as observed in unsaturated soil from upper part of column after the (Fig. 1), 14 day treatment. The combination of modified Fenton's reaction and cultivation slightly increased polycyclic aromatic hydrocarbon degradation and removed at most $54 \%$ of the polycyclic aromatic hydrocarbons (Fig. 1), 14 day treatment, soil from lower part of column. Earlier, biodegradation studies in combination with Fenton's reaction have been conducted as slurry phase treatment for clean-up of polycyclic aromatic hydrocarbons contaminated soil ${ }^{4,5}$. Increasing soil water content has been shown to increase the biodegradation of phenanthrene $^{21}$. In this study, the water content of incubated soil was up to $17 \%$, the effecting of water content on polycyclic aromatic hydrocarbons biodegradation sould be expertment meticulously.

Influence of modified Fenton's reaction on toxicity to Heterobasidion insulare: The toxicity of leachates and soil to Heterobasidion insulare was determined to show the effect of modified Fenton's react ion on overall toxicity (Table-3). After application of $\mathrm{H}_{2} \mathrm{O}_{2}$, bioluminescence was below detection in all assay wells after $0.5 \mathrm{~h}$ of cultivation of the microtiter plates and, therefore, $\mathrm{EC}_{50}$ values of the $0.5 \mathrm{~h}$ assay could not be determined. Leachate toxicity was higher in the experiment with 4 days treatment time. This could be due to increased bioavailability of the polycyclic aromatic hydrocarbons or presence of formed toxic contaminant metabolites ${ }^{15}$, since the oxidized polycyclic aromatic hydrocarbon metabolites have been shown to be more toxic to Heterobasidion insulare than the parent compounds ${ }^{8}$. Further, the oxidized polycyclic aromatic hydrocarbon metabolites can accumulate in soil ${ }^{22}$, which would indicate limited biodegradability. Whereas, there were literature shows that polycyclic aromatic hydrocarbon metabolites could be more biodegradable than the parent compounds ${ }^{23}$, thus the soil and leachate toxicity may decrease due to the biodegradation of the metabolites. In the control experiment, addition of deionized water, the flash assay toxicity was lower than the $0.5 \mathrm{~h}$ assay toxicity. Directly after the modified Fenton's reaction, the soil toxicity was similar for all soil samples, although soil heterogeneity caused higher variation than in for leachate toxicity measurements ${ }^{21}$. After cultivation, the toxicity in flash and $0.5 \mathrm{~h}$ assay was similar, but even after 16 weeks of cultivation. The treated soil was 5-10 times more toxic than untreated soil. The toxicity of soil from control column remained unchanged during cultivation and was similar to that of untreated soil ${ }^{24}$. Fig. 2 indicating that addition of $\mathrm{H}_{2} \mathrm{O}_{2}$ was more aggressive treatment than addition of deionized water.

The numbers of viable cells might be smaller than the numbers of intact cells, because it was shown that bacteria with intact cell walls can be nucleoid-free, therefore nonviable. In this that, the BacLight ${ }^{\circledR}$ live/dead assay should be combined with functional inspection such as cultivation and substrate utilization assays. During the 10-day experiment, the number of intact cells increased with longer cultivation (Fig. 2), although the percentage of viable cells was lower than in untreated soil. Since bacteria do persist in soil treated with modified Fenton's react ion, bio-augmentation of soil with polycyclic aromatic hydrocarbon-degrading bacteria may not be required. Furthermore, successful inoculation of soil with contaminant degrading bacteria is limited by the contaminant bioavailability ${ }^{25-28}$, especially in effect of modified Fenton's react ion on survival of intact, viable cells

The effect of the modified Fenton's reaction and subsequent cultivation on abundance and viability of cells was studied by enumerating viable (intact cell membrane) and dead (disrupted cell wall) cells. Cell wall disintegrations caused by $\mathrm{H}_{2} \mathrm{O}_{2}$ and radicals produced during the Fenton's reaction with carbamide peroxide ${ }^{29}$. Thus, with respect to this study, disruption of the cellular membrane is a reasonable indicator for cell death. Cells were more abundant in untreated soil than in the incubated Fenton's treated soil (Fig. 2). Right after modified Fenton's reaction, the cells were not enumerated because at that stage the checklist method was still under development. The lowest cell counts were found in incubated soil, which was intensively pretreated for 4 days. Cells with intact cell membrane were more abundant in untreated soil than in incubated Fenton's with carbamide peroxide treated soil (Fig. 2). In controller with deionized water, the percentage of intact cells was much higher after cultivation than in incubated oxidized soils contaminated with aged contaminants.

Extracellular enzymatic activity form microbial in soil: At the end of the 4-day experiment, the effect of the modified Fenton's react ion on microbial extra cellular enzyme activities was determined. Esterase activity was monitored with 4-MUF-acetate to assess general microbial activity. The activities of amino peptidase and acidic phosphomonoesterase, measured as $\mathrm{V}^{*}{ }_{\max }$, were studied to show if the hydrolysis of the respective enzyme substrates was affected by possible release of $\mathrm{N}$-and $\mathrm{P}$-containing compounds during the chemical treatment.

Aminopeptidase activities in soil from the control column receiving deionized water remained below detect ion limit.

TABLE-3

TOXICITY OF COLUMN LEACHATE TO Heterobasidion insulare IN FLASH AND $0.5 \mathrm{~h}$ TOXICITY TEST

\begin{tabular}{ccc|cc}
\hline Reaction time in modified Fenton's & \multicolumn{2}{c|}{ Flash test $\mathrm{EC}_{50}$ value } & \multicolumn{2}{c}{0.5 h test $\mathrm{EC}_{50}$ value } \\
\cline { 2 - 5 } treatment with carbamide peroxide & \multicolumn{2}{c|}{ Dilution factor } & $\%$ & \multicolumn{2}{c}{ Dilution factor } \\
\hline 1 week & 0.4 & 332.8 & 0.4 & 409.9 \\
2 weeks & 6.1 & 31.9 & 0.3 & 364.2 \\
3 weeks & 11.9 & 18.1 & 3.4 & 301.8 \\
4 weeks & 18.5 & 8.1 & 5.8 & 21.1 \\
5 weeks & 24.3 & 4.5 & 8.3 & 12.9 \\
\hline
\end{tabular}

$\mathrm{EC}_{50}$ values are given as percentage of the leachate after dilution and as dilution factor. 


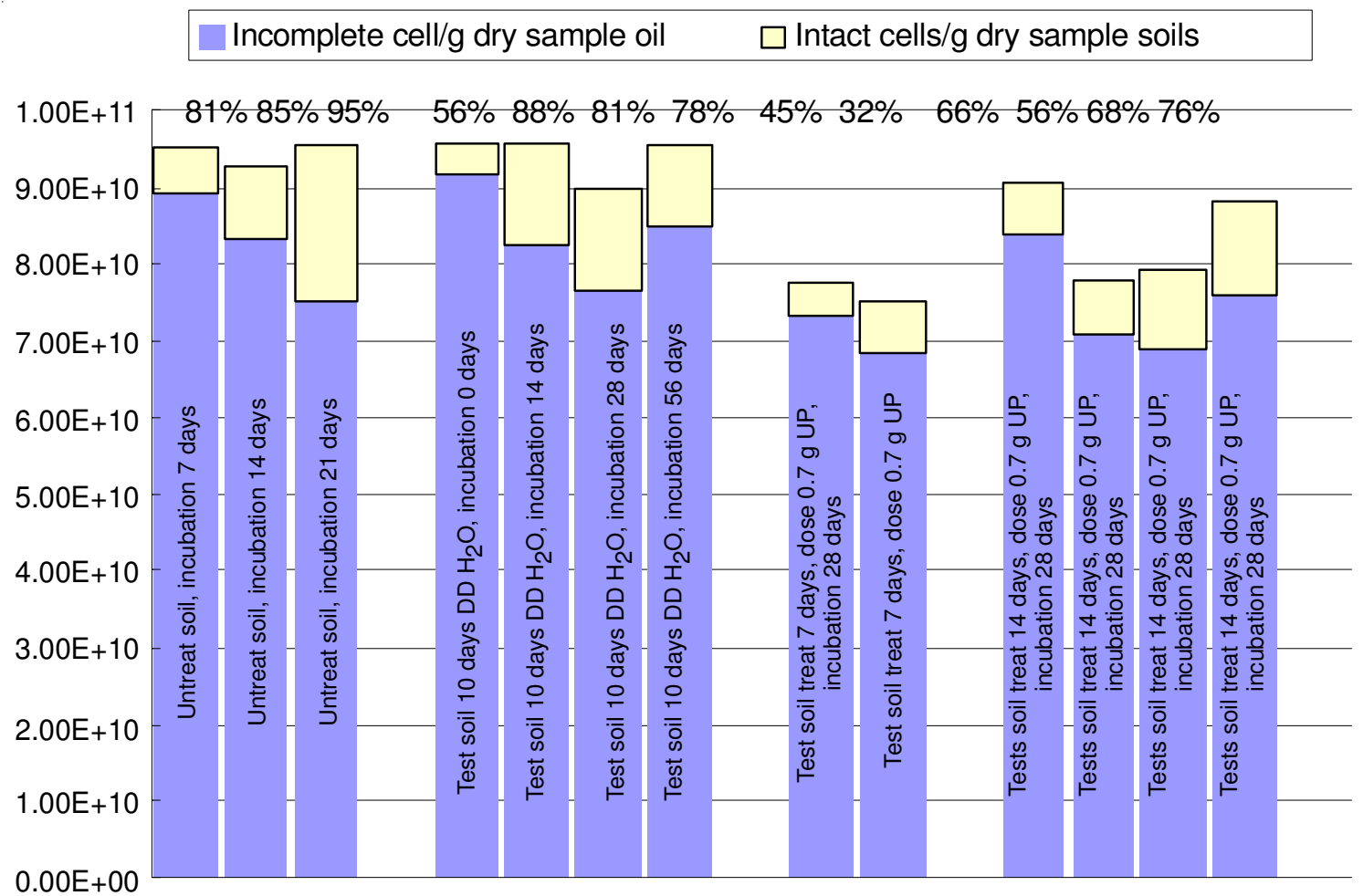

Fig. 2. Incomplete/intact cell Statistics and percentage of intact cells during incubation of sample soil and soil with application of deionized water and modified Fenton's reaction with carbamide peroxide

TABLE-4

COMPARE OF MICROBIAL EXTRACELLULAR ENZYME ACTIVITIES IN TREATED AND UNTREATED

\begin{tabular}{|c|c|c|c|c|c|c|c|}
\hline \multirow{2}{*}{$\begin{array}{l}\text { Cultivation } \\
\text { time (week) }\end{array}$} & \multirow{2}{*}{ Experiment } & & Serine & Leucine & Alanine & Acetate & Acidic phosphomono \\
\hline & & \multicolumn{4}{|c|}{ Aminopeptidase } & \multicolumn{2}{|r|}{ Esterase } \\
\hline 0 & Untreated soil & & 65 & 50 & 160 & 4400 & 1320 \\
\hline 5 & Untreated soil & & 50 & 40 & 40 & 2400 & 1750 \\
\hline 10 & Untreated soil & & 240 & 20 & 120 & 5200 & 1500 \\
\hline \multicolumn{8}{|c|}{ Soils sample gathering from column part } \\
\hline 5 & 10 days oxidation & $\uparrow$ & 45 & 70 & 40 & 2300 & 410 \\
\hline 5 & 10 days oxidation & $\downarrow$ & 135 & 100 & 185 & 500 & 250 \\
\hline 10 & 10 days oxidation & $\uparrow$ & $*$ & $*$ & 40 & 1070 & $*$ \\
\hline 10 & 10 days oxidation & $\downarrow$ & $*$ & $*$ & $*$ & 1650 & $*$ \\
\hline
\end{tabular}

*Means no enzyme saturation or no enzymatic activity observed.

Acetate esterase activities were lower in chemically treated soil than in untreated soil (Table-4). Furthermore, the esterase activities in soil taken from the lower part of columns were lower than in soil taken from the upper part of soil columns. Acetate esterase and aminopeptidase activities correlate with active biomass and can therefore be used to assess general metabolic activity of soil bacteria. Serine amino peptidase (Table-4) activities were highest in untreated incubated soil, while leucine amino peptidase activities were higher in Fenton treated soil. Amino peptidase activities either increased or decreased due to the modified Fenton's reaction (Table-4). The increase may be due to the increased availability of polymers containing amino acid group s after cell walls and natural organic matter structures have been degraded by the oxidants. The phosphomonoesterase activities (Table-4) were high in the untreated samples, indicating phosphorus deficiency of the soil bacteria. Therefore phosphate addition to the soil might support microbial growth and polycyclic aromatic hydrocarbonbiodegradation.
Monitoring gas during soil cultivation: Concentrations of $\mathrm{O}_{2}, \mathrm{CO}_{2}$ and $\mathrm{CH}_{4}$ were monitored during soil cultivation to determine microbial activity in the soil and biodegradation of organic-compounds (Fig. 3). Methane was not detected from the headspace of any serum bottle. Increase of oxygen concentrations above atmospheric concentration was observed in serum bottles with soil treated by modified Fenton's reaction during the first weeks of cultivation (Fig. 3). Although residual $\mathrm{H}_{2} \mathrm{O}_{2}$ was not determined from the soil itself, residual $\mathrm{H}_{2} \mathrm{O}_{2}$ was detected in the column leachate and formation of oxygen due to decomposition of residual $\mathrm{H}_{2} \mathrm{O}_{2}$ indicate presence of $\mathrm{H}_{2} \mathrm{O}_{2}$ in the soil incubated in serum bottles. In the serum bottles, aerobic conditions prevailed (Fig. 3), also indicated by the absence of methane.

Figure decomposition of $\mathrm{H}_{2} \mathrm{O}_{2}$ to $\mathrm{O}_{2}$ and $\mathrm{H}_{2} \mathrm{O}$ competes with the Fenton's reaction and causes an increase of carbamide peroxide consumption and was, therefore, not beneficial for the chemical oxidation of the contaminants. However, an increased oxygen concentration may facilitate biodegradation 


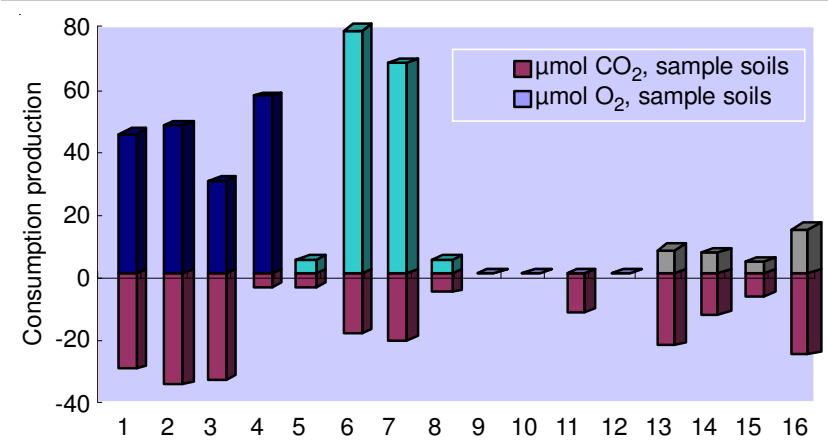

Fig. 3. Production and consumption of $\mathrm{O}_{2}$ and $\mathrm{CO}_{2}$ during incubation of untreated soil and soil with application of deionized water and modified Fenton's reaction with carbamide peroxide in service phases

of polycyclic aromatic hydrocarbons, since aerobic conditions have been shown to improve the biodegradation of polycyclic aromatic hydrocarbons. Carbamide peroxide is decomposed to $\mathrm{O}_{2}$ and $\mathrm{H}_{2} \mathrm{O}$ non-biological by iron minerals and biotical by the catalase enzyme. So far, methods to measure the activity of the $\mathrm{H}_{2} \mathrm{O}_{2}$ decomposing enzyme catalase are based on monitoring residual $\mathrm{H}_{2} \mathrm{O}_{2}$ or $\mathrm{O}_{2}$ formation after carbamide peroxide addition. Due to the abiotic processes applied in this study, these methods were neither applicable nor used.

During the cultivation, some of the polycyclic aromatic hydrocarbon degradation (Fig. 1) may be attributed to chemical oxidation, by both the radicals formed in Fenton react ion and residual $\mathrm{H}_{2} \mathrm{O}_{2}$. The $\mathrm{H}_{2} \mathrm{O}_{2}$ dose could be reduced to minimize adverse effects on the soil bacteria, based on the similar polycyclic aromatic hydrocarbon-degradation regardless of the applied $\mathrm{H}_{2} \mathrm{O}_{2}$ doses (Fig. 1) and initial $\mathrm{O}_{2}$ formation during cultivation (Fig. 3). Consumption of $\mathrm{O}_{2}$ was detected in untreated soil and soil treated by Fenton's reaction, although in the 4-day experiment $\mathrm{O}_{2}$ consumption was lower in soil samples from the upper part of soil column. Highest $\mathrm{O}_{2}$ consumption was found in untreated soil. In all the serum bottles with untreated soil and Fenton treated soil, formation of $\mathrm{CO}_{2}$ was observed. The $\mathrm{CO}_{2}$ formation was highest in the 10-day experiment. Biodegradation of polycyclic aromatic hydrocarbons as well as natural organic carbon could have contributed to the $\mathrm{CO}_{2}$ formation, since there was showed that Fenton's reaction dissolves organic carbon into soil solution and increases the biochemical oxygen demand of soil solution. The released and oxidized low molecular weight compounds may act as secondary substrates for the growth of the polycyclic aromatic hydrocarbon-degrading bacteria. In control bottles with twice autoclaved soil, untreated as well as treated soil, the concentrations of $\mathrm{O}_{2}$ and $\mathrm{CO}_{2}$ remained close to atmospheric concentrations throughout the cultivation. Thus, the microbial activity in the killed controls was low.

\section{Conclusion}

Polycyclic aromatic hydrocarbons can be partially removed, up to $52 \%$, by Fenton's reaction modified by addition of $30 \% \mathrm{H}_{2} \mathrm{O}_{2}$ solution to iron-rich soil without pre-acidification of the soil or ferrous iron supplementation. The modified Fenton's reaction causes increase of toxicity of leachate and soil to Heterobasidion insulare and inhibition to extracellular esterase activity of soil. The percentage of intact bacterial cells after cultivation is lower in soil treated with modified Fenton's reaction with carbamide peroxide compared to that of untreated soil. The combination of modified Fenton's reaction with subsequent aerobic biodegradation yields a slightly higher degradation of polycyclic aromatic hydrocarbons than the sole processes. The results were very different and variations may be caused by the strains used, methods and the reactor type. Even the influence of water during modified Fenton's reaction with carbamide peroxide may be very important for the production of carbamide peroxide products and their composition. There are still many aspects which need to be the subject of further investigations.

\section{ACKNOWLEDGEMENTS}

The study has been supported by the Natural Science Foundation of Heilongjiang Province (No. C201214).

\section{REFERENCES}

1. N.M. Ram, D.H. Bass, R. Falotico and M. Leahy, J. Soil Contamin., 2, 167 (1993).

2. S.K. Samanta, O.V. Singh and R.K. Jain, Trends Biotechnol., 20, 243 (2002).

3. B. Liang, R. Li, D. Jiang, J. Sun, J. Qiu, Y. Zhao, S. Li and J. Jiang, Curr. Microbiol., 61, 226 (2010).

4. M.R.T. Palmroth, J.H. Langwaldt, T.A. Aunola, A. Goi, U. Münster, J.A. Puhakka and T.A. Tuhkanen, Biodegradation, 17, 29 (2006).

5. R. Venkatadri and R.W. Peters, Hazard. Waste Hazard. Mater, 10, 107 (1993).

6. K. Nam, W. Rodriguez and J.J. Kukor, Chemosphere, 45, 11 (2001).

7. A.K. Haritash and C.P. Kaushik, J. Hazard. Mater., 169, 1 (2009).

8. J.L. Sims, R.C. Sims and J.E. Matthews, Hazard. Waste Hazard. Mater., 7, 117 (1990).

9. D.P. Chambers and P.M. Attiwill, Aust. J. Bot., 42, 739 (1994).

10. Venny, S.Y. Gan and H.K. Ng, Chem. Eng. J., 213, 295 (2012).

11. Q.Y. Cai, C.H. Mo, Q.T. Wu, Q.-Y. Zeng and A. Katsoyiannis, Chemosphere, 68, 1751 (2007).

12. T.A. Aunola, A. Goi, M.R.T. Palmroth, J.H. Langwaldt and T.A. Tuhkanen, J. Adv. Oxid. Technol., 9, 11 (2006).

13. M.L. Rock, B.R. James and G.R. Helz, Environ. Sci. Technol., 35, 4054 (2001).

14. M.R.T. Palmroth, J.H. Langwaldt, T.A. Aunola, A. Goi, J.A. Puhakka and T.A. Tuhkanen J. Chem. Technol. Biotechnol., 81, 598 (2006).

15. T.M. Phillips, D. Liu, A.G. Seech, H. Lee and J.T. Trevors, J. Ind. Microbiol. Biotechnol., 24, 132 (2000).

16. F.D. Kopinke, J. Poerschmann and U. Stottmeister, Environ. Sci. Technol., 29, 941 (1995).

17. M.E. Lindsey and M.A. Tarr, Environ. Sci. Technol., 34, 444 (2000).

18. M.G. Zemanek, S.J.T. Pollard, S.L. Kenefick and S.E. Hrudey, Environ. Pollut., 98, 239 (1997).

19. G. Cornelissen, Ö. Gustafsson, T.D. Bucheli, M.T. O. Jonker, A.A. Koelmans and P.C.M. van Noort, Environ. Sci. Technol., 39, 6881 (2005).

20. K.T. Semple, A.W.J. Morriss and G.I. Paton, Eur. J. Soil Sci., 54, 809 (2003).

21. M.B. McBride, B.K. Richards, T. Steenhuis, J.J. Russo and S. Sauvé, Soil Sci., 162, 487 (1997).

22. L. Launen, L. Pinto, C. Wiebe, E. Kiehlmann and M. Moore, Can. J. Microbiol., 41, 477 (1995).

23. R. Meulenberg, H.H. Rijnaarts, H.J. Doddema and J.A. Field, FEMS Microbiol. Lett., 152, 45 (1997).

24. L. Lazzeri and L.M. Manici, Hort Sci., 36, 1283 (2001).

25. S.M. Dean, Y. Jin, D.K. Cha, S.V. Wilson and M. Radosevich, J. Environ. Qual., 30, 1126 (2001).

26. M. Kästner, M. Breuer-Jammali and B. Mahro, Appl. Environ. Microbiol., 64, 359 (1998).

27. B.W. Bogan and W.R. Sullivan, Chemosphere, 52, 1717 (2003).

28. T. Madsen and P. Kristensen, Environ. Toxicol. Chem., 16, 631 (1997).

29. H.F. Diao, X.Y. Li, J.D. Gu, H.C Shi and Z.M Xie, Process Biochem., 39, 1421 (2004). 